\title{
HDAC inhibitors in experimental liver and kidney fibrosis
}

\author{
Katrien Van Beneden ${ }^{1 * \dagger}$, Inge Mannaerts ${ }^{2^{*}}$, Marina Pauwels ${ }^{1}$, Christiane Van den Branden ${ }^{1}$ \\ and Leo A van Grunsven ${ }^{2}$
}

\begin{abstract}
Histone deacetylase (HDAC) inhibitors have been extensively studied in experimental models of cancer, where their inhibition of deacetylation has been proven to regulate cell survival, proliferation, differentiation and apoptosis. This in turn has led to the use of a variety of HDAC inhibitors in clinical trials. In recent years the applicability of HDAC inhibitors in other areas of disease has been explored, including the treatment of fibrotic disorders. Impaired wound healing involves the continuous deposition and cross-linking of extracellular matrix governed by myofibroblasts leading to diseases such as liver and kidney fibrosis; both diseases have high unmet medical needs which are a burden on health budgets worldwide. We provide an overview of the potential use of HDAC inhibitors against liver and kidney fibrosis using the current understanding of these inhibitors in experimental animal models and in vitro models of fibrosis.
\end{abstract}

Keywords: Histone deacetylase, HDAC and liver, Kidney or hepatic, Renal fibrosis

\section{Introduction}

Both chronic kidney and chronic liver diseases have high unmet medical needs, which progressively strain health budgets worldwide. The chronic nature of both conditions and the need for long term therapy are the basis for this global burden on the healthcare systems. In addition, chronic liver disease (CLD) and chronic kidney disease (CKD) are considered as disorders with high mortality. It is estimated that annually $>100,000$ new patients are diagnosed with CLD in the United States, contributing to the increasing number of patients who need organ replacement therapy [1]. Furthermore, about $40 \%$ of patients on a waiting list do not receive a liver transplant due to donor shortage. A recent EASL report states that approximately 29 million EU inhabitants are affected by some degree of progressive liver disease, which equals to $6 \%$ of the population [2-5]. The mortality rate for CKD and diseases of the urinary tract is about 850,000 deaths every year, which ranks CKD, like

\footnotetext{
*Correspondence: katrien.van.beneden@vub.ac.be; inge.mannaerts@vub.ac.be ${ }^{\dagger}$ Equal contributors

${ }^{1}$ Department of Human Anatomy, Liver Cell Biology Lab, Vrije Universiteit Brussel, Brussels, Belgium

${ }^{2}$ Department of Cell Biology, Liver Cell Biology Lab, Vrije Universiteit Brussel, Brussels, Belgium
}

\section{() Biomed Central

(c) 2013 Van Beneden et al.; licensee BioMed Central Ltd. This is an Open Access article distributed under the terms of the Creative Commons Attribution License (http://creativecommons.org/licenses/by/2.0), which permits unrestricted use, distribution, and reproduction in any medium, provided the original work is properly cited.
CLD, in the top 15 of high mortality disorders. Moreover, CKD is associated with an 8- to 10-fold increase in cardiovascular mortality and is a risk multiplier in patients with diabetes and hypertension. Although more common in developing countries, disadvantaged and minority populations, at least $8 \%$ of the population of Europe currently has some degree of CKD, which means that roughly 40 million people are affected in the EU. This figure increases each year and if the present trend endures, the number of people with CKD will double over the next decade [6-10].

\section{Review}

Fibrosis

Tissue damage triggers both inflammatory and repair responses that in the case of repeated or chronic injury results in fibrosis. In organ or tissue fibrosis, the equilibrium of extracellular matrix (ECM) formation and degradation is impaired, resulting in excessive deposition of ECM by an eminent population of myofibroblasts [11]. This dysregulated biosynthetic process, leading to the accumulation of ECM, can be due to damage from ischemia, chemical agents, viral and nonviral infections, physical injury or immunological attack. The fibrotic architecture or ECM deposition can be visualized 
experimentally through commonly used histological stainings, for example, Periodic Acid Schiff, MassonTrichrome or Picrosirius Red.

Fibrosis is not only restricted to glomerulosclerosis and tubulointerstitial fibrosis in kidney or cirrhosis in liver; there are also pulmonary fibrosis in the lungs, endomyocardial fibrosis in the heart, myelofibrosis in the bone marrow, scleroderma in the skin, Crohn's disease in the intestine, and systemic sclerosis in skin and lungs. In all these organs, fibrosis is characterized by the persistence of ECM-producing myofibroblasts, ineffective re-epithelialization and variable degrees of inflammation within the injured tissues [12]. Cellularly, the 'classical' source of ECM proteins is due to the expansion and activation of resident fibroblasts into ECMproducing myofibroblasts (Figure 1). Other origins of mesenchymal cells, responsible for the exaggerated and uncontrolled production of collagen and other ECM proteins in fibrotic disorders is a topic of ongoing research and is yet to be completely elucidated [13-17]. Extensive studies suggest that most myofibroblasts are derived from tissue-specific fibroblasts and pericytes [18-20]. Other possible sources are bone marrowderived circulating fibrocytes or mesenchymal stem cells [21-23]. Endothelial cells were also recently found to be capable of undergoing endothelial-to-mesenchymal transition (EndoMT) in the kidney [24]. Finally, epithelial cells of both the liver and kidney are implied to be able to undergo epithelium-to-mesenchymal transition (EMT) in vitro as seen during embryogenesis and tumor metastasis, even though the origin of ECM-proteins from epithelial cells are a controversial topic in vivo [20,25-28]. Recent studies concerning EMT during liver and kidney fibrosis have employed lineage tracing in different animal models. Some of the confusion may originate from the use of sometimes unspecific markers, such as fibroblast-specific protein 1 (Fsp1, S100A4) and the use of transgenic mice models in a not entirely appropriate setting [20,27,29-32]. Excellent reviews describing the potential role of EMT in both kidney and liver disease are available for further reading [25,33,34]. The markedly increasing number of myofibroblasts during the fibrotic process will lead to structural abnormalities and decreased organ functions, leading inevitably to further disease progression where, for now, artificial or organ replacement therapy is the only outcome.

\section{Hepatic fibrosis}

Fibrosis, or scarring of the liver, is a chronic woundhealing response that recruits a range of cell types and mediators to intercept the injury caused by viral infections, auto-immune, cholestatic and metabolic diseases

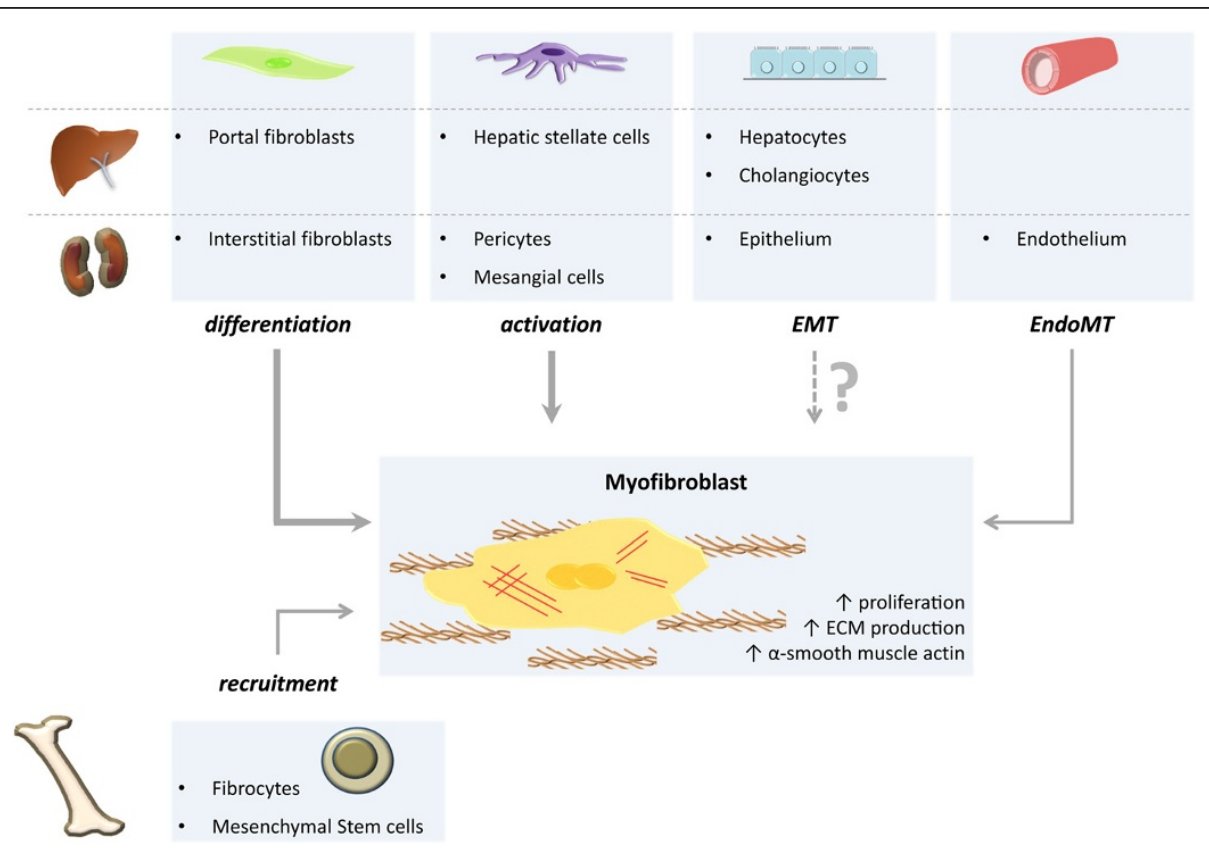

Figure 1 Possible origins of myofibroblast-like cells in liver and kidney. It is recognized that the fibrogenic cells in both liver and kidney are heterogeneous in their origin and behavior. In general, matrix-producing cells in chronic wound repair are derived from resident fibroblasts, respectively portal fibroblasts in the liver and interstitial fibroblasts in the kidney. Besides fibroblasts, the major contributors to the excessive ECM deposition are specialized pericytes, such as hepatic stellate cells and mesangial cells. In vitro and in vivo evidence is available for the possibility of epithelial-to-mesenchymal transition (EMT) and endothelial-to-mesenchymal transition (EndoMT). Finally, several studies have suggested that bone marrow-derived stem cells or fibrocytes could transdifferentiate within adult tissues to form mature matrix-producing cells; however, the amount of ECM produced by these cells appears to be negligible. 
as well as drugs or alcoholic-induced injury [1]. A cell type implicated in several important facets of CLD are hepatic stellate cells (HSCs), as they are the most important source of matrix and the main origin of myofibroblasts in the liver, which renders them an important target for the treatment of liver fibrosis [35]. HSCs are a small sinusoidal liver cell population, representing $\pm 8 \%$ of liver cells. This key cell type, influencing the balance of matrix secretion and degradation, favoring the accumulation of collagen during fibrogenesis, resides in perisinusoidal recesses between adjacent hepatocytes and projects long processes (approximately $50 \mu \mathrm{m}$ ) into the space of Disse parallel to the sinusoidal endothelial cells [17]. In the adult liver, HSCs are quiescent and are implicated in the uptake, storage and release of vitamin A. About $75 \%$ of the vitamin A stored in the liver is accumulated in cytoplasmatic lipid droplets in the stellate cells, in the form of retinyl-esters [36].

Another hallmark of the HSCs in normal livers is the balanced synthesis and degradation of the ECM that accounts for about $0.5 \%$ of the liver weight. HSCs secrete many cytokines (for example, platelet derived growth factor (PDGF), transforming growth factor- $\beta$ (TGF), interleukines) and also respond to them in an autocrine manner [37,38]. Following acute or chronic liver injury of any etiology, HSCs are activated and become myofibroblast-like cells. This activation, or transdifferentiation towards an activated phenotype, is promoted by a number of pro-inflammatory cytokines, such as TGF- $\beta$ and PDGF $[39,40]$. Phenotypically, the activated HSCs become proliferating, myofibroblast-like cells that acquire a well-developed stress fiber cytoskeleton. Additionally, they lose their capacity to store vitamin A and start to produce excessive amounts of ECM, causing scar formation and thereby providing the fundamental needs for tissue repair [41,42]. HSC activation is the result of an orchestrated process that can be divided in three main phases: 1) initiation, 2) perpetuation and 3) resolution. The initiation phase of HSC activation starts by paracrine signals, which include early changes in ECM composition as a result of increased fibronectin secretion by liver sinusoidal endothelial cells, which leads to mild gene expression changes that render HSCs more cytokine sensitive. Continuous exposure to the paracrine and autocrine cytokines will cause perpetuation of the activated phenotype and will lead to a net increase in ECM production. The third step of HSC activation is potentially the most crucial to understand in order to develop anti-fibrotic treatments, since it implies the resolution of fibrosis. How the number of activated HSCs decreases remains uncertain, but it may be the result of HSC apoptosis or reversal from the activated to the quiescent or inactivated phenotype [37,43-47]. Next to the contribution of HSCs to chronic liver injury, recent papers revealed a role of activated HSCs in acute liver injury. During acute injury, the number of activated HSCs $\left(\alpha \mathrm{SMA}^{+}\right)$increases rapidly and profibrotic gene expression is quickly induced, this leads to regenerative fibrosis that is resolved upon regeneration [48,49]. In contrast to chronic injury, upon acute damage the inhibition of HSC activation could be negative for recovery.

Due to limited availability of human study material, in vitro studies of the mechanisms underlying mouse or rat HSC activation have shown to be very informative (Figure 2). Cells can be isolated from rodent livers and when plated on culture dishes, cells spontaneously undergo a process comparable to the in vivo HSC activation upon liver injury. In addition, the use of animal models has provided essential insights into fibrogenesis, which helped researchers to extrapolate observations in animal models to a more clinical setting. Some frequently used mouse and rat models for liver disease are carbon tetrachloride $\left(\mathrm{CCl}_{4}\right)$ or thioacetamide (TAA)-induced intoxication or invasive methods like the common bile duct ligation (CBDL) model [50].

\section{Kidney: glomerulosclerosis and tubulointerstitial fibrosis}

The kidneys, part of the excretory system, receive approximately $20 \%$ of the cardiac output and are morphological versatile organs, which can be divided into the cortex and medulla. In the renal cortex numerous highly specialized blood filtration units, the glomeruli, can be found surrounded by a network of tubules. The glomerulus itself is also a multiform structure consisting of an intricately folded basement membrane (GBM), which separates the fenestrated endothelial cells and mesangial cells from the podocytes (top right panel Figure 2). Whereas the conventional course of renal fibrosis is dependent on the location of the onset, many diseases affect kidney function by attacking the glomeruli. When the integrity of this system is attacked, a series of stereotypical architectural lesions occurs [51]. Loss of podocytes may lead to areas of "bare" GBM, which represents a potential starting point of irreversible glomerular disease. These areas of denuded GBM are the site of bulk leakage of plasma proteins through the glomerular filter. The parietal epithelium is then triggered to attach to the denuded GBM; this tuft adhesion to Bowman's capsule being the point-of-no-return. Focal architectural lesions have a tendency to develop into more widespread structural lesions which further progress to full-blown sclerosis. As the podocyte is a specialized differentiated nonproliferating cell, podocyte injury is an apparent trigger for glomerulosclerosis [52]. On the other hand, lesions of the glomerular endothelium can contribute to the underlying pathogenesis of progressive glomerular diseases, as seen in preeclampsia. Glomerular endothelial dysfunctions affect the surrounding microenvironment, 

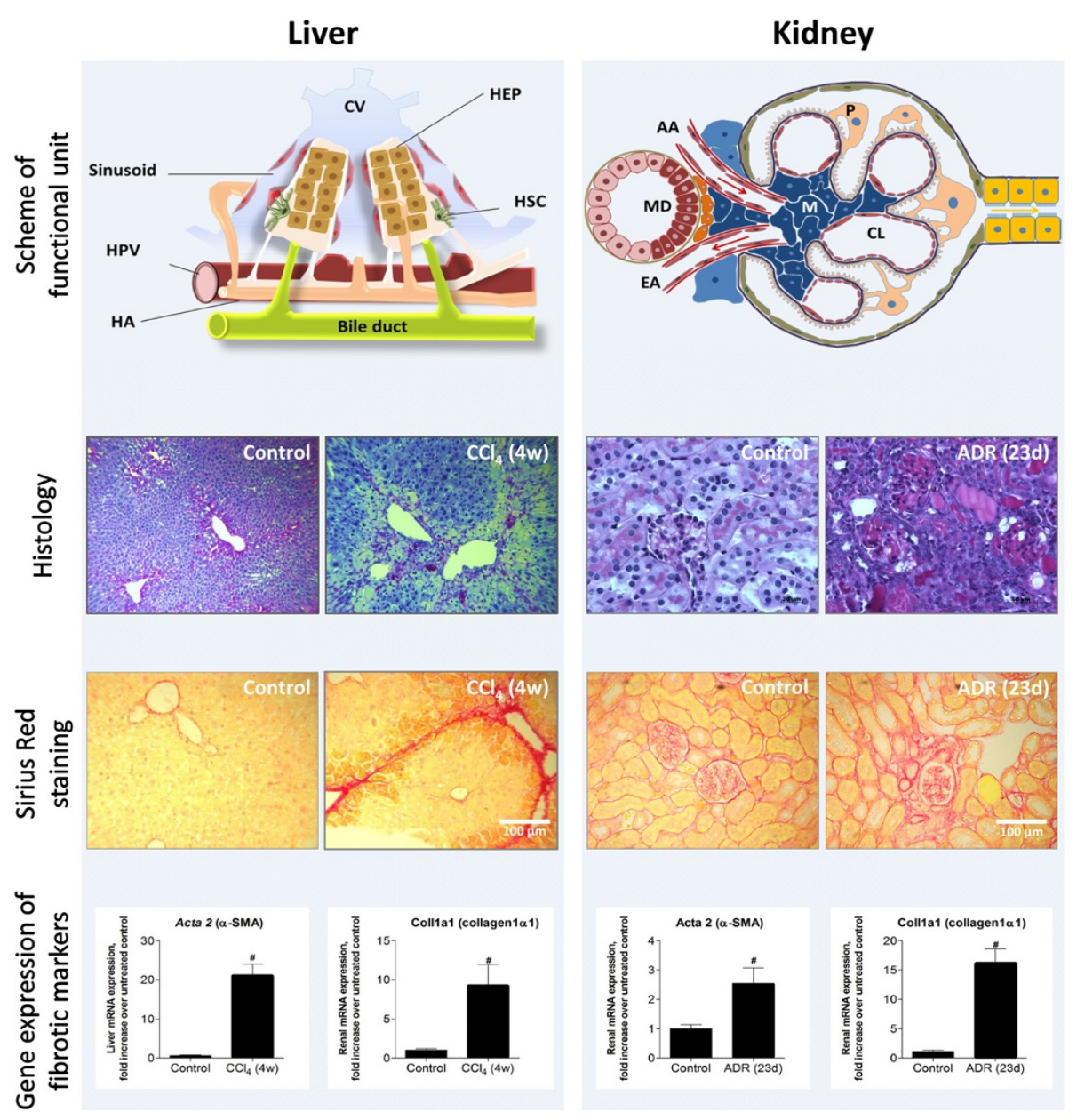

Figure 2 Multidisciplinary techniques for characterization of $\mathrm{CCl}_{4}$-induced liver fibrosis and ADR-induced renal fibrosis. Although the liver and kidneys are very distinct organs, common techniques are available for detection of fibrotic damage in them. The top panel shows schemes of the functional units of the kidneys and liver, respectively the glomerulus and the hepatic lobule. Histological staining, Periodic Acid Schiff (PAS) or hematoxylin staining can be performed to study histological changes and are frequently combined with a Sirius Red staining to quantify the degree of matrix deposition or scar formation. Finally, QPCR analysis can provide further information on changes in gene expression upon organ fibrosis. Well-known markers are collagen 1 and alpha-smooth muscle actin, both representing the presence of matrix-producing myofibroblasts. $\mathrm{CCl}_{4}$-induced liver fibrosis was induced by intraperitoneal injection of carbon tetrachloride $(50 \mu \mathrm{g} / 100 \mathrm{~g}$ body weight) twice a week for four weeks in BalbC male mice. ADR-induced renal fibrosis was induced by a single intravenous injection of adriamycin (10 mg/kg body weight) and female mice were sacrificed 23 days after ADR injection. The study protocol was approved by the Institutional Animal Care and Use Committee of Vrije Universiteit Brussel, permit numbers 10-212-3 and 09-217-1 and National Institutes of Health principles of laboratory animal care (NIH publication 86-23, revised 1995) were followed. AA, afferent arteriole; $C L$, capillary loop; CV, central vein; EA, efferent arteriole; HA, hepatic artery; HEP, hepatocyte or hepatocytes; HPV, hepatic portal vein; HSC, hepatic stellate cell; $M$, mesangial cell; MD, macula densa; $P$, podocyte.

thereby accelerating renal disease progression [53]. Mesangial cells are the third population that can play an obvious role in a wide range of glomerular diseases. Embedded in their own ECM, the mesangial cells have a supporting function and can be considered as a specialized pericyte for the glomerular microvasculature. The amount and composition of mesangial ECM is tightly regulated and clearly altered during disease by generation of a variety of inflammation mediators, such as cytokines, chemokines and growth factors. These cellular events, which can be found during diabetic nephropathy, for example, will lead toward mesangial cell proliferation and matrix expansion [54]. Moreover, gene mutations of the GBM collagen type IV also give rise to severe pathological conditions, the most well-known being Alport syndrome, the most common hereditary nephropathy $[55,56]$. Clinical features of this X-linked syndrome are defects in the GBM resulting in hematuria, progressive nephritis with proteinuria and declining renal function $[57,58]$.

Irrespective of the primary cause, most types of CKD are characterized by the development of progressive 
renal tubulointerstitial fibrosis [59]. In other words, in many cases glomerular diseases, such as FSGS (focal segmental glomerulosclerosis) eventually lead to tubulointerstitial fibrosis [60,61]. Tubulointerstitial fibrosis is defined as the excessive accumulation of ECM in the interstitium surrounding the tubules. The prominently increasing number of myofibroblasts, derived among others from the resident interstitial fibroblasts, will result in abnormal alterations in kidney structure. These injuries are correlated with loss in renal function and will eventually lead to end-stage renal failure (ESRF) [62].

To study the process of renal fibrosis various models are available [63]; in the past the most widely used experimental approach was to reduce renal mass (remnant kidney) $[64,65]$. Since the 1950s, puromycin aminonucleoside nephrosis (PAN) has become an experimental prototype for the pathological process of human minimal change disease (MCD) and FSGS [66,67]. The critical role of podocyte-specific genes in the mediation of FSGS has been shown by inducible gene silencing in podocytes, where proof of concept is given that the mutation/deletion of a particular gene (for example, nephrin, podocin) is sufficient to cause proteinuria and FSGS in human hereditary diseases $[68,69]$. The Thy-1.1 mouse nephropathy model can also be used for the study of FSGS $[70,71]$. The most well-established mouse model for human FSGS is the adriamycin-induced nephropathy model [72-75], while unilateral ureteral obstruction (UUO) has been extensively studied as a model where the initial insult is located in the tubulointerstitial compartment, characterized by tubular epithelial injury and cell death [76].

\section{HDACs}

Acetylation of nucleosomal histones on the $\varepsilon$-amino group of lysine residues was first discovered in 1968. However, it was not until the mid-1990s before the enzymes responsible for the balance between the acetylated/ deacetylated states of histones, namely histone acetyltransferases (HATs) and histone deacetylases (HDACs) were identified. Histone acetylation restores the positive charge of lysine residues, loosening their interaction with negatively-charged DNA. These changes in chromatin structure facilitate the accessibility of transcription factors and, consequently, gene transcription can occur. On the contrary, deacetylation will result in tightly wrapped DNA and transcriptional repression. In general, HDACs have an opposing function to HATs, with HATs promoting and HDACs silencing gene transcription [77-80]. In addition, acetylation of non-histone proteins like transcription factors themselves can affect their DNA binding properties, thus regulating gene expression. Numerous cytoplasmic proteins, such as tubulin and heat shock protein 90, can be (de)acetylated, altering their function. HDACs can, therefore, also be referred to as lysine deacetylases (KDACs) to more precisely describe their function rather than their targets [81-83].

Dependent on sequence similarity and cofactor dependency, HDACs are grouped into four classes and two families: the 'classical' and the silent information regulator 2 (Sir2)-related protein (sirtuin) families. The 'classical' HDACs require $\mathrm{Zn}^{2+}$ for their deacetylase activity and comprises three classes; Class I (HDAC1, 2, 3 and 8 ), which are widely expressed and almost exclusively located in nuclei, Class II (HDAC4, 5, 6, 7, 9 and 10) and Class IV (HDAC11), which are expressed in a tissue-specific manner and are primarily located in the cytoplasm but can shuttle to the nucleus [83-87]. Class III HDACs belongs to the sirtuin family, which contains seven members (SIRT1-7) with no sequence resemblance to members of the classical family, requiring $\mathrm{NAD}^{+}$as a cofactor. These $\mathrm{NAD}^{+}$-dependent protein acetylases are localized in the nucleus (SIRT1, SIRT6 and SIRT7), mitochondria (SIRT3-SIRT5) and cytoplasm (SIRT2) [88-90].

\section{HDAC inhibitors}

HDAC inhibitors are exciting compounds with anticancer properties, altering gene expression to induce death, differentiation and/or cell-cycle arrest of tumor cells. These inhibitors interact with the catalytic domain of HDACs and subsequently interfere with the function of HDACs. Inhibitors of the $\mathrm{Zn}^{2+}$ dependent HDACs can be divided in several different classes, due to their structural differences, including hydroxamic acids, cyclic peptides, electrophilic ketones, short-chain fatty acids and benzamides. The structural diversity among HDAC inhibitors suggests that the mechanism of action may involve other interactions on top of its HDAC contact to account for the deacetylase activity of the inhibitor $[86,87,91]$. The HDAC inhibitor trichostatin A (TSA) is a hydroxamic acid, which was extensively studied and found to have important applications in cancer therapy [92-96]. Studies in a variety of mammalian tumor cell lines, revealed that the antiproliferative activity of TSA is due to an increase in histone acetylation. Nanomolar concentrations of TSA are able to potently and reversibly inhibit histone deacetylases. The activity of Class I, II and IV HDACs is affected, while sirtuins (Class III HDACs) remain TSA-insensitive [97]. The high potency and specificity of TSA makes it a prototypical compound and a very useful tool for studying the effects of HDAC inhibition. However, TSA has only limited clinical use, as it is metabolized within 30 minutes by the hepatocytes [98]. Investigators, therefore, developed more stable and safer drugs without sacrificing HDAC inhibitory potency $[99,100]$, with a well-known TSA analog being vorinostat or SAHA (suberoylanilide hydroxamic 
acid) $[101,102]$. Both TSA and SAHA are so called panHDAC inhibitors, influencing the activity of HDACs 1 through 11 with roughly equivalent efficiency $[87,103]$.

Among the growing list of HDAC inhibitors we also find the short chain fatty acid valproic acid (VPA, 2propylpentanoic acid), which is considered primarily a Class I HDAC inhibitor. VPA, first used as an organic solvent, turned out to have anticonvulsive properties on its own [104]. Recently, valproic acid was shown to have antifibrotic effects both in a model for liver fibrosis as in the experimental adriamycin-induced nephropathy model $[105,106]$. Commercially, VPA is available as Depakene ${ }^{\circledR}$ (Sanofi, Paris, France) and its use in clinic ranges from an anticonvulsant, mood-stabilizing drug to a drug against depression, migraines and schizophrenia. Due to the HDAC inhibitory property of VPA, this well-tolerated anticonvulsive drug, has in addition been extensively studied as an antineoplastic agent [107-113].

Currently, there are more than 100 clinical trials recruiting patients, where the anticancer efficiency of HDAC inhibitors, like vorinostat and panobinostat, two TSA-analogues, is tested. Both these HDAC inhibitors, including entinostat, are being investigated for renal cell carcinoma, while only panobinostat is currently explored for hepatocellular carcinoma [114].

The currently used HDAC inhibitors in recruiting and ongoing clinical trials are summarized in Table 1 (source: clinicaltrials.gov). Despite their difference in potency and selectivity towards certain HDACs, the various inhibitors in general lead to growth arrest, differentiation and apoptosis of malignant cells $[115,116]$. It should be noted that next to histones, also many non-histone proteins can be dynamically (de)acetylated. Many of them are important oncogenes and tumor suppressors, such as MYC, p53 and PTEN $[81,82]$.

In the last part of this review, we will focus on studies that investigated the use of HDAC inhibitors as potential antifibrotics through the use of in vitro and in vivo models of both liver and kidney disease.

\section{HDACs and HDAC inhibitors in liver fibrosis}

Niki et al. were the first to explore the anti-fibrotic effects of HDAC-inhibitors in a model for stellate cell activation. A first in vitro study showed that both sodium butyrate and TSA could modulate rat stellate cell activation. Collagen 1 and 3 and $\alpha$-smooth muscle actin ( $\alpha$-SMA) up-regulation was blocked by HDAC inhibition and proliferation was decreased upon treatment, with a pronounced better potential for TSA [117]. Later studies by the Geerts lab, revealed that TSA treatment led to alterations in actin cytoskeleton forming components. They described how TSA induced a down-regulation of actin related proteins 2 and 3 (Arp2, Arp3) and RhoA, and an up-regulation of two capping proteins: adducinglike protein 70 (ADDL70) and gelsolin. These effects were translated in reduced stellate cell migration

Table 1 Overview of most frequently used HDAC inhibitors in the currently recruiting clinical trials

\begin{tabular}{|c|c|c|c|c|}
\hline Name & Alternative names & HDACs inhibited & \# of clinical trials & Disease \\
\hline Vorinostat & $\begin{array}{l}\text { N1-hydroxy-N8-phenyl- } \\
\text { octanediamide, SAHA, } \\
\text { Suberoylanilide Hydroxamic } \\
\text { Acid, Zolinza }\end{array}$ & Class I and II & 72 & $\begin{array}{l}\text { Breast Cancer; Ovarian, Fallopian Tube, or Peritoneal } \\
\text { Cancer; Prostate Cancer; Soft Tissue Sarcoma; Non-Small } \\
\text { Cell Lung Cancer; Solid Tumors with/without HIV } \\
\text { infection; Gastric cancer; Multiple Myeloma; Multiple } \\
\text { Lymphoid Malignancies, such as Leukemia, Mantle Cell } \\
\text { Lymphoma; Large B-Cell Lymphoma; T-Cell Lymphoma; } \\
\text { Hodgkin Lymphoma, B-Cell Non-Hodgkin Lymphoma, } \\
\text { Myelodysplastic Syndromes or Myeloproliferative } \\
\text { Disorders; Adenoid Cystic Carcinoma; Head and Neck } \\
\text { Cancer; Brain Metastasis; Neuroblastoma; Glioma; } \\
\text { Glioblastoma Multiforme; Embryonal Tumors of the } \\
\text { Central Nervous System; Metastatic Melanoma of the Eye; } \\
\text { Graft-Host Disease; Renal Cell Carcinoma }\end{array}$ \\
\hline Panobinostat & LBN-589; LBH589; NVP-LBH589 & Class I, II and IV & 23 & $\begin{array}{l}\text { Myelodysplastic Syndrome; Metastatic Gastric Cancer; } \\
\text { Breast Cancer; B-Cell Lymphoma; Leukemia; Graft-Host } \\
\text { Disease; Renal Cell Carcinoma; Hodgkin's Lymphoma; } \\
\text { Lung Cancer; Prostate Cancer; Hepatocellular Carcinoma; } \\
\text { T-Cell Lymphoma; Chordoma }\end{array}$ \\
\hline Valproic acid & $\begin{array}{l}\text { Dipropylacetic acid, VPA, } \\
\text { myproic acid, Depakene }\end{array}$ & Class I & 12 & $\begin{array}{l}\text { Sarcoma; Myelodysplastic Syndrome; Leukemia; } \\
\text { Lymphoma; Gliomas; Cervical Cancer; Ovarian cancer }\end{array}$ \\
\hline Entinostat & SNDX-275; MS-27-275, MS-275 & $\mathrm{HDAC} 1,3$ & 6 & $\begin{array}{l}\text { Leukemia; Renal Cell Carcinoma; Resected Stage I } \\
\text { Non-Small Cell Lung Cancer }\end{array}$ \\
\hline Belinostat & PXD101; PX105684 & Class I, II and IV & 2 & Small Cell Lung Carcinoma; Lymphomas \\
\hline CUDC-101 & $\begin{array}{l}\text { 7-((4-((3-ethynylphenyl)amino)-7- } \\
\text { methoxyquinazolin-6-yl)oxy)-N- } \\
\text { hydroxyheptanamide }\end{array}$ & $\begin{array}{l}\text { multitargeted } \\
\text { HDAC, EGFR and } \\
\text { HER2 inhibitor }\end{array}$ & 2 & Head and Neck Cancers \\
\hline
\end{tabular}

Table source: clinicaltrials.gov. 
following incubation with TSA $[118,119]$. Although, this was a promising kick-off for antifibrotic studies of HDAC inhibitors, information on effects of TSA treatment in in vivo models of liver injury is limited. As seen by Sirius red staining, TSA administration hampers collagen deposition in $\mathrm{CCl}_{4}$ treated rats (unpublished data). A more recent study by Zhang et al. showed the protective effects of TSA on liver injury in a mouse model for sepsis. During sepsis, the liver is not only an important actor in the host defensive response, but it will also suffer from the dysregulation of inflammatory mediators. TSA treatment of mice that underwent cecal ligation and puncture resulted in lower serum levels of transaminases and increased the presence of anti-inflammatory interleukin 10 (IL-10). This suggests that TSA alleviated hepatic injury following sepsis [120]. In a lipopolysaccharide (LPS) induced model for sepsis, SAHA administration decreased activation of MAP kinases (p38 and ERK) in vivo, which might explain the described improvement in sepsis-induced liver injury [121]. These studies all focused on the observed antifibrotic effects upon HDAC inhibition rather than on the role of individual HDACs or mechanisms underlying the potential of the used compounds. In contrast, a recent study by Elsharkawy determined a role for HDAC1 in the NF- $\mathrm{KB}$ orchestrated regulation of MMP13 expression. Overexpression of p50 in a human stellate cell line LX2 could suppress MMP13 expression. In addition, the authors show that the presence of $\mathrm{p} 50$ is essential for recruitment of HDAC1 to the MMP13 promoter, by performing chromatin immunoprecipitation (ChIP) on freshly isolated HSCs from Nfkb-/- (p50-deficient) and wild type mice. TSA was employed as a tool to show that inhibition of HDAC activity could prevent the p50induced repression of MMP13 expression. Together, this could explain the overexpression of MMP13 in HSCs from Nfkb-/- compared to wild type animals, but this then seems to be contradictory to the increased susceptibility of these $\mathrm{Nfkb}-/-$ mice to $\mathrm{CCl}_{4}$. While MMP13 is a protease involved in degradation of fibrillar collagen, this matrix remodeling also leads to release of matrix bound inactive profibrogenic cytokines contributing to inflammation and disease progression [122]. This recent study confirmed earlier data on repression of TNF $\alpha$ by HDAC1 in stellate cells, using the same transgene mouse model [122,123]. Other reports emphasizing a role of HDAC enzymes during liver fibrosis used 2,4,6'Tris(methoxymethoxy) chalcone (TMMC), VPA and ectopic HDAC4 expression, respectively $[105,124,125]$. TMMC reduced the number of $\alpha$-SMA expressing cells by induction of apoptosis of activated stellate cells at high concentrations [124]. In the study by Qin, the role of HDAC4, a member of Class II HDACs, was investigated in an in vitro model. They show that ectopic
HDAC4 expression in stellate cells regulates expression of MMP9 and MMP13 following IL-1 stimulation [125]. A report on the role of HDAC6 in alcohol-induced alterations in Wif-B liver cells, (a hybrid of human fibroblasts and Fao rat hepatoma cells), showed a decreased HDAC6 expression after alcohol or TSA treatment and this resulted in changes in microtubule dynamics. However, the authors did not evaluate the impact of these changes on cell polarity or liver injury [126]. In the study by Mannaerts et al., it was shown that VPA administration inhibits stellate cell activation in vitro and in vivo. The in vivo effect was investigated by treating mice with carbontetrachloride and VPA and subsequent isolation of hepatic stellate cells. These cells had lower profibrotic gene expression levels compared to cells isolated from mice treated with $\mathrm{CCl}_{4}$ alone. The observed effects were partially due to inhibition of Class I HDAC activity, since the VPA effect could be in part mimicked by siRNA mediated knockdown of the Class I HDACs. The knock-down of class I HDACs in contrast to VPA treatment did not affect $\alpha$-SMA expression, but strongly reduced the expression of matrix remodeling enzyme lysyl oxidase [105].

In conclusion, most HDAC-inhibitor liver studies focus on the effects on disease development or reversal, without having a closer look at the molecular mechanisms of the inhibition. As a result, the contribution of the individual HDACs to liver disease still remains unclear. A role for Class I HDACs has been described [105,122,123,127], but also the expression of Class II HDACs was documented in liver biopsies of hepatocellular carcinoma patients. The expression of Class II HDACs (HDAC4, 5, 6, 7, 9 and 10) were gradually elevated from normal to cirrhotic and HCC livers. This trend was closely related to progressive up-regulation of MEF2, suggesting a link among HDAC activity, MEF2 expression, stellate cell activation and the degree of liver disease [128]. It is clear that HDACs have emerged as interesting targets for anti-fibrotic therapy and that further exploration of their individual function and the possibility for therapeutic intervention is meaningful. In addition, two recent papers [46,47] elegantly showed that upon recovery from liver injury, the activated myofibroblasts can be reverted to stellate cells presenting a more quiescent phenotype. Studies by Niki et al. [117] and Mannaerts et al. [105] have shown that in vitro this process of HSC reversal can be stimulated by HDAC inhibitor treatment, indicating that the in vivo process of conversion to stellate cell quiescence could be accelerated by HDAC inhibitory treatment.

The effects of HDAC inhibition on stellate cell activation are not only interesting for the fibrosis field, but also for the development of anti-hepatocellular carcinoma treatment. Hepatocarcinogenesis is modulated by 
the cross-talk of malignant hepatocytes with surrounding stromal cells. In vitro and in vivo studies provide evidence that stellate cells increase hepatocellular growth, EMT, invasiveness and tumor volume [129-133]. Recently, it was shown that treatments have differential effects on the two compartments and targeting of HDACs using TSA can influence this bidirectional cross-talk $[134,135]$. In these studies, an immortalized HSC cell line was used and additional research with primary HSCs could further support this promising therapeutic strategy.

\section{HDACs and HDAC inhibitors in kidney fibrosis}

In 2002, a renal cell line was exposed to an HDAC inhibitor for the first time [136]. Yu et al. showed that the excessive NO (nitric oxide) production, correlating with glomerular disease, can be limited by an HDAC inhibitor. TSA was shown to restrain not only the induction of endogenous NO in mesangial cells, but also iNOS (inducible nitric oxide synthase) promoter activity in response to cytokines, such as IL-1ß. Overexpression experiments further revealed that HDAC2 could augment the induction of iNOS promoter activity [137]. In a later study, the inhibition of iNOS in mesangial cells by TSA was shown to be regulated by phosphoinositide3-kinase- (PI3K) and p70s6-kinase-dependent pathways, controlled by epigenetic histone H4 modifications [138]. In addition, both TSA and VPA could inhibit mesangial cell proliferation and hamper collagen and $\alpha$-SMA synthesis. TSA was further shown to interfere with cell cycle progression by specifically blocking the G1/S transition. Moreover, TSA-treated mesangial cells were shown to have a flattened stellate-shaped morphology, comparable to hepatic stellate cells [139].

Recently, CTGF (connective tissue growth factor), in collaboration with TGF- $\beta$, was shown to promote the development of fibrosis in a variety of fibrotic models both in the liver and kidneys [140]. The expression of CTGF in renal endothelial and epithelial cells can be influenced by HDAC inhibitors [141-143]. Interestingly, the expression of CTGF was differentially regulated by different HDAC inhibitors. CTGF was clearly up-regulated when endothelial cells were incubated with TSA, sodium butyrate and SAHA, nevertheless VPA was found to be less effective [141]; while in epithelial cells, CTGF expression was dependent on culture confluency and donor variability [142,143].

Besides exposing glomerular cells to HDAC inhibitors, a number of studies on cells of the tubulointerstitial compartment, that is, proximal tubular epithelial cells or interstitial fibroblasts, have explored the in vitro effect of HDAC inhibitors. Peinado et al. showed that down-regulation of E-cadherin in proximal tubular epithelial cells under TGF$\beta$-stimulated culture conditions involved Snail-mediated recruitment of the Sin3A/HDAC1/HDAC2 complex [144]. This prompted researchers to further study the effect of HDAC inhibitors on tubulointerstitial cells in vitro, as elaborately reviewed by Pang et al. [145]. In short, TGF-beta1induced EMT-like morphological changes can be prevented when exposing proximal tubular epithelial cells to TSA [143]. In addition, TSA was also found to restore CREB (cAMP-responsive element binding protein) function in the cisplatin-induced cytotoxic model [146]. Initially, conflicting results for apoptosis were described when proximal tubular epithelial cells were treated with either TSA or SAHA $[147,148]$, where further studies of the Fujita group clearly show that TSA prevents TGF-beta1-induced apoptosis by inhibiting ERK activation [149]. In vitro knockdown studies of HDAC1, in both renal interstitial fibroblasts and tubular epithelial cells, showed that HDAC1 is involved in fibroblast proliferation and chemokine production [150,151]. In contrast, however, HDAC1 was demonstrated to be recruited as a co-repressor to the promoters of IL-6 and IL-12b under ischemia/reperfusion (I/ $\mathrm{R}$ ) injury in proximal tubular epithelial cells, and in vivo silencing of HDAC1 enhanced renal dysfunction induced by I/R injury [152]. This report implies that HDAC inhibitory therapy will not have a protective effect, although the possible use of HDAC inhibitors as a therapy for renal fibrosis was established in UUO [151,153,154], streptozotocininduced diabetic nephropathy [155-157], other ischemia models [158,159], and adriamycin nephropathy [106].

Again using the HDAC inhibitor TSA, researchers showed the inhibition of both $\alpha$-SMA expression and STAT3 phosphorylation in the mouse UUO model [154], while FR276457 (pan-HDAC inhibitor) was able to exert a prophylactic effect against renal interstitial fibrosis by inhibiting monocyte chemotactic protein-1 (MCP-1) production [153]. TSA was shown to reduce macrophage infiltration in the UUO model, where additional in vitro experiments suggest that HDAC1 and HDAC2 may modulate proinflammatory responses in early stages of tubulointerstitial injury [151]. In streptozotocin-induced diabetic kidneys, TSA reduces the expression of ECM components and prevented EMT [157]. In the same model, vorinostat (SAHA) attenuated early renal enlargement and authors showed that this effect is most likely mediated, or at least in part, by down-regulation of the epidermal growth factor receptor (EGFR) [156]. The same group also showed the reduction of endothelial nitric oxidase synthase (eNOS) in the attenuation of diabetic nephropathy by SAHA [155]. Recently, Van Beneden et al. showed that VPA can prevent kidney injury and proteinuria in the murine adriamycin nephropathy model when chronic VPA administration was started prior to the adriamycin insult. Furthermore, when postponing VPA administration, renal disease progression was attenuated and the established proteinuria was corrected. VPA could hamper 
kidney disease progression by inhibiting glomerular apoptosis and proliferation induced by adriamycin [106]. These data further confirm the notion that HDAC inhibitors can abrogate renal inflammation and fibrosis, as was seen in other renal injury models discussed earlier [151,153,154,156-159]. The possible antiproteinuric effect of HDAC inhibitors was also observed in the rat Thy-1.1induced glomerulonephritis model. In this study, both TSA and VPA were found to significantly suppress proteinuria ( 25 to $51 \%$ and 39 to $68 \%$, respectively) [139]. In the streptozotocin-induced diabetic nephropathy model, TSA was able to reduce proteinuria by approximately 35\% [157].

Together these in vivo animal studies confirm the notion that HDAC inhibitors can abrogate renal inflammation and fibrosis, as nicely discussed in the recent review by Brilli et al. [160]. However, we want to stress that only a small number of studies have explored the effects of HDAC inhibitors on glomerular cells in vitro, where specific data on HDAC inhibition in podocytes are lacking thus far. In conclusion, more research should be done to reveal the mechanism by which HDAC inhibitors can reduce in vivo fibrosis and proteinuria.

\section{Conclusions}

A great deal of work is still needed to fully understand the mechanisms of fibrogenesis, but a substantial amount of progress has been made over the years. When we reflect on literature discussed in this review, we find that HDAC inhibitors are potential antifibrotic agents for both liver and kidney fibrosis, as the common mechanisms of fibrosis like ECM accumulation and inflammation can be reduced with the therapy of HDAC inhibitors (Figure 3). The modulation of the immune response by HDAC inhibitors has been extensively described in some recent reviews and is not unique to fibrosis. In general, HDACs play a role in leukocyte differentiation and survival, regulate the function of macrophages and dendritic cells by controlling inflammatory mediator production and can possibly modulate Toll-like receptor and interferon signaling pathways [161,162].

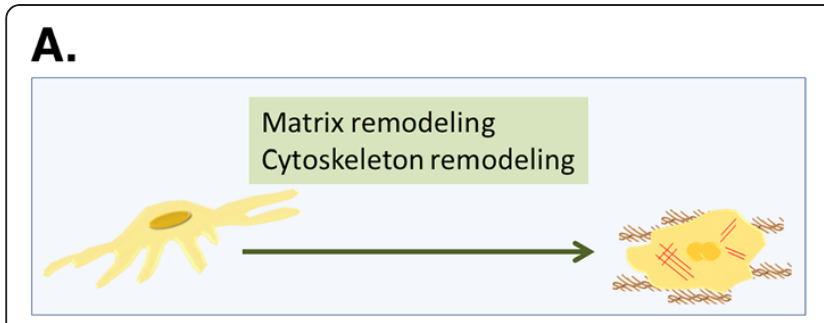

B.

HEPATIC STELLATE CELL ACTIVATION
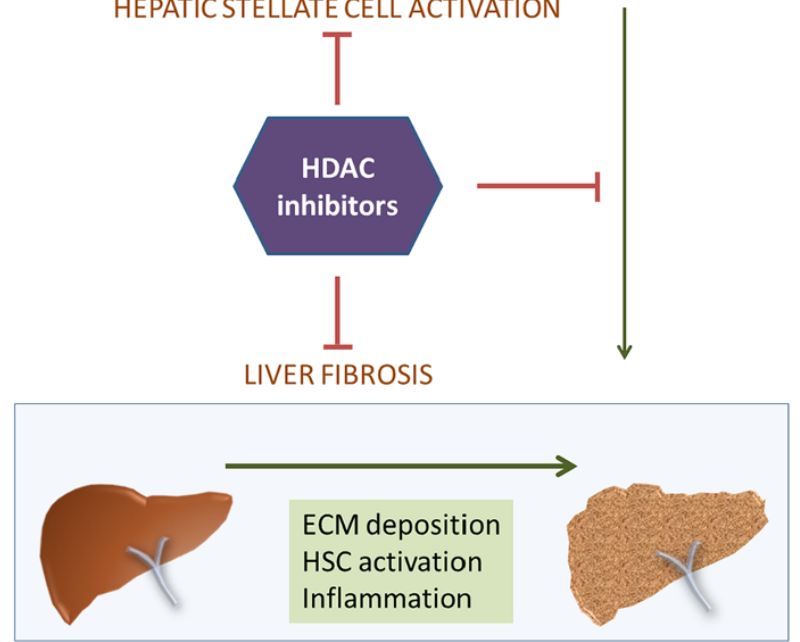
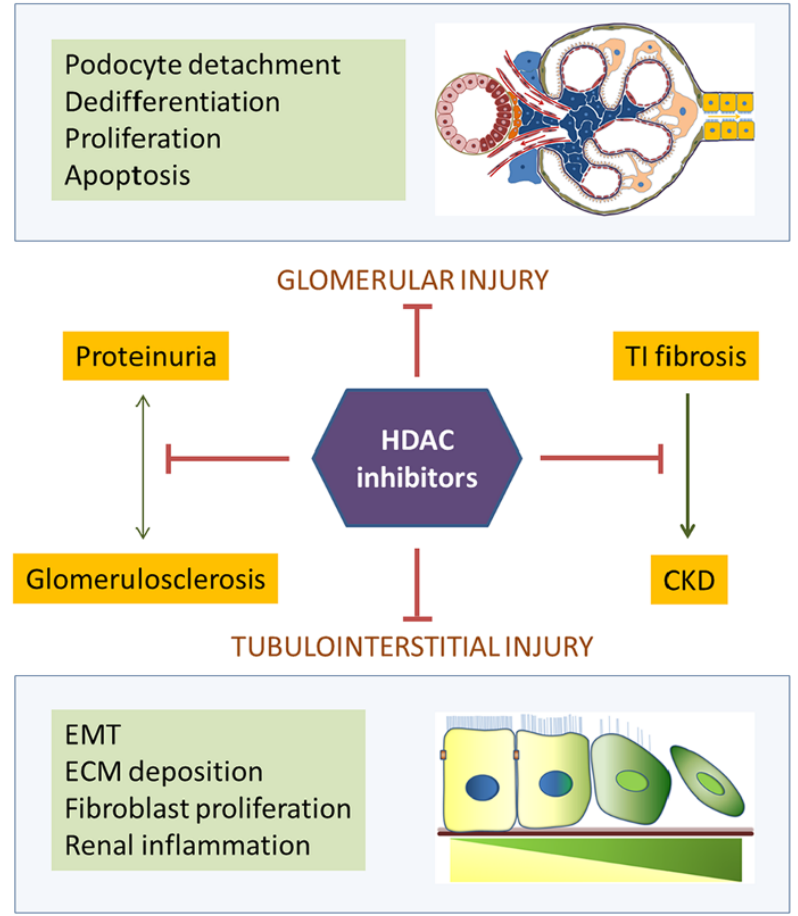

EMT

ECM deposition

Fibroblast proliferation

Renal inflammation

Figure 3 Overview of processes affected by HDAC inhibition in liver and kidney fibrosis. In experimental models of both liver and kidney fibrosis the beneficial effects of HDAC inhibitors have been reported as discussed in this review. (A) Specifically for liver, most studies have focused on the effects on stellate cell activation. Different aspects of this process have been described, such as, for example, the effects on matrix remodeling proteins. By inhibiting HSC activation, the development of fibrosis can be inhibited. (B) In kidneys, the favorable properties of HDAC inhibitors can be found in both the glomerular and tubulointerstitial compartment, where processes, such as proliferation, apoptosis, ECM deposition and inflammation, are hampered. Abrogating the pathological processes of glomerulosclerosis and tubulointerstitial (TI) fibrosis can potentially inhibit the development and progression of chronic kidney disease (CKD). 
In general, inhibition of HDAC activity will lead to increased histone acetylation, which in turn will mostly result in gene activation, thus the diminution of the expression of inflammatory and fibrotic genes in an experimental setting is most likely due to indirect targeting through miRNAs or other transcriptional repressors. In the given overview, we find that mostly pan- or class I specific HDAC inhibitors are being used in the field of liver and kidney fibrosis. Further research dissecting the individual role of each HDAC during fibrosis would, therefore, be very interesting; this would contribute to the development of selective inhibitors that are more tolerable and effective. A possible good candidate with joined relevance in the pathological process of kidney and liver fibrosis might be HDAC1, as previously discussed. The development of a specific inhibitor remains challenging, since the catalytic site of all HDAC enzymes is highly conserved and thus most HDAC inhibitors will obstruct the catalytic site of all HDAC enzymes [163]. Despite our focus on (de)acetylation, we are aware of the possible additive effects of the inhibition of methylation during fibrosis. In preclinical cancer studies that combined an HDAC inhibitor with a demethylating agent (for example, 5 'azacytidine), beneficial effects have been observed $[164,165]$. The combination of HDAC inhibitors and 5 'azacytidine could possibly be valuable for treatment of fibrosis in patients, as recent publications pointed out roles for methylation in hepatic stellate cells and in kidney fibrosis [45,166-168].

To conclude, we only highlighted the promising findings on HDAC inhibition in liver and kidney fibrosis, but the intrinsic role of HDACs in fibrogenesis of other organs becomes clear [169-171]. While originally appreciated for their anticancer properties, a growing body of evidence now supports the safety and efficacy of HDAC inhibitors in experimental models of liver and kidney disease, potentially expanding their clinical application.

\footnotetext{
Abbreviations

a-SMA: alpha-smooth muscle actin; ADDL70: Adducing-like protein 70; Apr2/ 3: actin related proteins2 and 3; CBDL: Common bile duct ligation; CCl4: Carbon tetrachloride; ChIP: chromatin immunoprecipitation; CKD: Chronic kidney disease; CLD: Chronic liver disease; CREB: CAMPresponsive element binding protein; CTGF: connective tissue growth factor; EASL: European association for the study of the liver; ECM: Extracellular matrix; EGFR: epidermal growth factor receptor; EMT: Epithelium-tomesenchymal transition; EndoMT: Endothelial-to-mesenchymal transition; eNOS: Endothelial nitric oxidase synthase; ERK: Extracellular signal-regulated kinase; ESRF: End-stage renal failure; EU: European union; FSGS: Focal segmental glomerulosclerosis; Fsp1: Fibroblast-specific protein 1; GBM: Glomerular basement membrane; HAT: Histone acetyltransferase; HDAC: Histone deacetylase; HSCs: Hepatic stellate cells; IL-10: Interleukin 10; iNOS: Inducible nitric oxide synthase; I/R: Ischemia/reperfusion; KDAC: Lysine deacetylase; LPS: Lipopolysaccharide; MCD: Minimal change disease; MCP1: Monocyte chemotactic protein-1; MMP13: Matrix metalloproteinase 13; NAD+: Nicotinamide adenine dinucleotide; NF-kB: Nuclear factor-kappa B; NO: Nitric oxide; PAN: Puromycin aminonucleoside nephrosis; PI3K: Phosphoinositide-3-kinase; PDGF: Platelet derived growth factor; RhoA: Ras homolog gene family, member A; SAHA: Suberoylanilide
}

hydroxamic acid; Sir2: Silent information regulator 2; TAA: Thioacetamide; TGF- $\beta$ : Transforming growth factor-beta; TMMC: $2^{\prime}, 4^{\prime}, 6^{\prime}$-Tris(methoxymethoxy) chalcone; TNF-a: Tumor necrosis factor-alpha; TSA: Trichostatin A;

UUO: Unilateral ureteral obstruction; VPA: Valproic acid.

\section{Competing interests}

The authors declare that they have no competing interests.

\section{Authors' contributions}

$I M$ and KVB did the research and writing. MP, CVdB and LVG performed the editing. All authors read and approved the final manuscript.

\section{Acknowledgements}

I. Mannaerts and L. A. van Grunsven are supported by the Vrije Universiteit Brussel through a Geconcerteerde Onderzoeksactie (GOA48 and GOA78) project and by the Fund for Scientific Research Flanders (FWO-V) (G.0260.09). K. Van Beneden and C. Van den Branden are supported by the Vrije Universiteit Brussel through an Onderzoeksraad project (OZR1428 and OZR1796).

Received: 19 October 2012 Accepted: 29 November 2012

Published: 2 January 2013

\section{References}

1. Adam R, Karam V, Delvart V, O'Grady J, Mirza D, Klempnauer J, Castaing D, Neuhaus P, Jamieson N, Salizzoni M, Pollard S, Lerut J, Paul A, Garcia-Valdecasas JC, Rodríguez FS, Burroughs A, all contributing centers (www.eltr.org); European Liver and Intestine Transplant Association (ELITA): Evolution of indications and results of liver transplantation in Europe. A report from the European Liver Transplant Registry (ELTR). J Hepatol 2012, 57:675-688.

2. European Association for the Study of the Liver: EASL Annual Report 2009. Geneva, Switzerland: European Association for the Study of the Liver; 2010.

3. Kamath PS, Wiesner RH, Malinchoc M, Kremers W, Therneau TM, Kosberg CL, D'Amico G, Dickson ER, Kim WR: A model to predict survival in patients with end-stage liver disease. Hepatology 2001, 33:464-470.

4. Yu Y, Fisher JE, Lillegard JB, Rodysill B, Amiot B, Nyberg SL: Cell therapies for liver diseases. Liver Transp/ 2012, 18:9-21.

5. Adam R, McMaster P, O'Grady JG, Castaing D, Klempnauer JL, Jamieson N, Neuhaus P, Lerut J, Salizzoni M, Pollard S, Muhlbacher F, Rogiers X, Garcia Valdecasas JC, Berenguer J, Jaeck D, Moreno Gonzalez E, European Liver Transplant Association: Evolution of liver transplantation in Europe: report of the European Liver Transplant Registry. Liver Transp/ 2003, 9:1231-1243.

6. Couser WG, Remuzzi G, Mendis S, Tonelli M: The contribution of chronic kidney disease to the global burden of major noncommunicable diseases. Kidney Int 2011, 80:1258-1270.

7. James MT, Hemmelgarn BR, Tonelli M: Early recognition and prevention of chronic kidney disease. Lancet 2010, 375:1296-1309.

8. Narayan KM, Ali MK, Koplan JP: Global noncommunicable diseases-where worlds meet. N Engl J Med 2010, 363:1196-1198.

9. Schieppati A, Remuzzi G: Chronic renal diseases as a public health problem: epidemiology, social, and economic implications. Kidney Int Supp/ 2005, 98:S7-S10.

10. EKHA: The European Kidney Health Alliance, 2011. www.ekha.eu.

11. Hinz B, Phan SH, Thannickal VJ, Prunotto M, Desmoulière A, Varga J, De Wever O, Mareel M, Gabbiani G: Recent developments in myofibroblast biology: paradigms for connective tissue remodeling. Am J Pathol 2012, 180:1340-1355.

12. Wynn TA: Cellular and molecular mechanisms of fibrosis. J Pathol 2008 , 214:199-210.

13. Hinz B: Formation and function of the myofibroblast during tissue repair. J Invest Dermatol 2007, 127:526-537.

14. Hinz B: The myofibroblast: paradigm for a mechanically active cell. J Biomech 2010, 43:146-155.

15. Hinz B, Gabbian G: Fibrosis: recent advances in myofibroblast biology and new therapeutic perspectives. F1000 Biol Rep 2010, 2:78

16. Hinz B, Phan SH, Thannickal VJ, Galli A, Bochaton-Piallat ML, Gabbiani G: The myofibroblast: one function, multiple origins. Am J Pathol 2007, 170:1807-1816.

17. Forbes SJ, Parola M: Liver fibrogenic cells. Best Pract Res Clin Gastroenterol 2011, 25:207-217. 
18. Lin SL, Kisseleva T, Brenner DA, Duffield JS: Pericytes and perivascular fibroblasts are the primary source of collagen-producing cells in obstructive fibrosis of the kidney. Am J Pathol 2008, 173:1617-1627.

19. Meran S, Steadman R: Fibroblasts and myofibroblasts in renal fibrosis. Int $J$ Exp Pathol 2011, 92:158-167.

20. Humphreys BD, Lin SL, Kobayashi A, Hudson TE, Nowlin BT, Bonventre JV, Valerius MT, McMahon AP, Duffield JS: Fate tracing reveals the pericyte and not epithelial origin of myofibroblasts in kidney fibrosis. Am J Pathol 2010, 176:85-97.

21. Herzog EL, Bucala R: Fibrocytes in health and disease. Exp Hematol 2010, 38:548-556

22. Quan TE, Cowper S, Wu SP, Bockenstedt LK, Bucala R: Circulating fibrocytes: collagen-secreting cells of the peripheral blood. Int J Biochem Cell Biol 2004, 36:598-606.

23. Higashiyama R, Moro T, Nakao S, Mikami K, Fukumitsu H, Ueda Y, Ikeda K, Adachi E, Bou-Gharios G, Okazaki I, Inagaki Y: Negligible contribution of bone marrow-derived cells to collagen production during hepatic fibrogenesis in mice. Gastroenterology 2009, 137:1459-1466.e1.

24. Zeisberg EM, Potenta SE, Sugimoto H, Zeisberg M, Kalluri R: Fibroblasts in kidney fibrosis emerge via endothelial-to-mesenchymal transition. J Am Soc Nephrol 2008, 19:2282-2287.

25. Fragiadaki M, Mason RM: Epithelial-mesenchymal transition in renal fibrosis - evidence for and against. Int J Exp Pathol 2011, 92:143-150.

26. Liu Y: New insights into epithelial-mesenchymal transition in kidney fibrosis. J Am Soc Nephrol 2010, 21:212-222.

27. Quaggin SE, Kapus A: Scar wars: mapping the fate of epithelialmesenchymal-myofibroblast transition. Kidney Int 2011, 80:41-50.

28. Zeisberg M, Duffield JS: Resolved: EMT produces fibroblasts in the kidney. J Am Soc Nephrol 2010, 21:1247-1253.

29. Taura K, Miura K, Iwaisako K, Osterreicher CH, Kodama Y, Penz-Osterreicher M, Brenner DA: Hepatocytes do not undergo epithelial-mesenchymal transition in liver fibrosis in mice. Hepatology 2010, 51:1027-1036.

30. Scholten D, Osterreicher CH, Scholten A, Iwaisako K, Gu G, Brenner DA, Kisseleva T: Genetic labeling does not detect epithelial-to-mesenchymal transition of cholangiocytes in liver fibrosis in mice. Gastroenterology 2010, 139:987-998.

31. Chu AS, Diaz R, Hui JJ, Yanger K, Zong Y, Alpini G, Stanger BZ, Wells RG: Lineage tracing demonstrates no evidence of cholangiocyte epithelialto-mesenchymal transition in murine models of hepatic fibrosis. Hepatology 2011, 53:1685-1695.

32. Iwano M, Plieth D, Danoff TM, Xue C, Okada H, Neilson EG: Evidence that fibroblasts derive from epithelium during tissue fibrosis. J Clin Invest 2002, 110:341-350.

33. Pinzani M: Epithelial-mesenchymal transition in chronic liver disease: fibrogenesis or escape from death? J Hepatol 2011, 55:459-465.

34. Cook HT: The origin of renal fibroblasts and progression of kidney disease. Am J Pathol 2010, 176:22-24.

35. Geerts $A$ : On the origin of stellate cells: mesodermal, endodermal or neuro-ectodermal? J Hepatol 2004, 40:331-334.

36. Blomhoff $R$, Wake K: Perisinusoidal stellate cells of the liver: important roles in retinol metabolism and fibrosis. FASEB J 1991, 5:271-277.

37. Friedman SL: Hepatic stellate cells: protean, multifunctional, and enigmatic cells of the liver. Physiol Rev 2008, 88:125-172

38. Geerts A: History, heterogeneity, developmental biology, and functions of quiescent hepatic stellate cells. Semin Liver Dis 2001, 21:311-335.

39. Pinzani M, Marra F: Cytokine receptors and signaling in hepatic stellate cells. Semin Liver Dis 2001, 21:397-416.

40. Dooley S, ten Dijke P: TGF-beta in progression of liver disease. Cell Tissue Res 2012, 347:245-256.

41. Kent G, Gay S, Inouye T, Bahu R, Minick OT, Popper H: Vitamin A-containing lipocytes and formation of type III collagen in liver injury. Proc Natl Acad Sci U S A 1976, 73:3719-3722

42. McLean AJ, Morgan DJ: Clinical pharmacokinetics in patients with liver disease. Clin Pharmacokinet 1991, 21:42-69.

43. Kisseleva T, Brenner DA: Anti-fibrogenic strategies and the regression of fibrosis. Best Pract Res Clin Gastroenterol 2011, 25:305-317.

44. Pinzani M, Rombouts K: Liver fibrosis: from the bench to clinical targets. Dig Liver Dis 2004, 36:231-242.

45. Bechtel W, McGoohan S, Zeisberg EM, Müller GA, Kalbacher H, Salant DJ, Müller CA, Kalluri R, Zeisberg M: Methylation determines fibroblast activation and fibrogenesis in the kidney. Nat Med 2010, 16:544-550.
46. Kisseleva $T$, Cong M, Paik Y, Scholten D, Jiang C, Benner C, Iwaisako K, Moore-Morris T, Scott B, Tsukamoto H, Evans SM, Dillmann W, Glass CK, Brenner DA: Myofibroblasts revert to an inactive phenotype during regression of liver fibrosis. Proc Natl Acad Sci U S A 2012, 109:9448-9453.

47. Troeger JS, Mederacke I, Gwak GY, Dapito DH, Mu X, Hsu CC, Pradere JP, Friedman RA, Schwabe RF: Deactivation of hepatic stellate cells during liver fibrosis resolution in mice. Gastroenterology 2012, 143:1073-1083.

48. Dechêne A, Sowa JP, Gieseler RK, Jochum C, Bechmann LP, El Fouly A, Schlattjan M, Saner F, Baba HA, Paul A, Dries V, Odenthal M, Gerken G, Friedman SL, Canbay A: Acute liver failure is associated with elevated liver stiffness and hepatic stellate cell activation. Hepatology 2010, 52:1008-1016.

49. Rastogi A, Bihari C, Maiwall R, Ahuja A, Sharma MK, Kumar A, Sarin SK: Hepatic stellate cells are involved in the pathogenesis of acute-on-chronic liver failure (ACLF). Virchows Arch 2012, 461:393-398

50. Starkel P, Leclercq IA: Animal models for the study of hepatic fibrosis. Best Pract Res Clin Gastroenterol 2011, 25:319-333.

51. Jennette JC, Olson JL, Schwarz MM, Silva FG: Heptinstall's Pathology of the Kidney. 6th edition. Philadelphia, PA: Lippincott Williams \& Wilkins; 2007.

52. Kriz W, Gretz N, Lemley KV: Progression of glomerular diseases: is the podocyte the culprit? Kidney Int 1998, 54:687-697.

53. Hennessy A, Makris A: Preeclamptic nephropathy. Nephrology (Carlton) 2011, 16:134-143

54. Schlondorff D, Banas B: The mesangial cell revisited: no cell is an island. J Am Soc Nephrol 2009, 20:1179-1187.

55. Hanson $\mathrm{H}$, Storey $\mathrm{H}$, Pagan J, Flinter F: The value of clinical criteria in identifying patients with X-linked Alport syndrome. Clin J Am Soc Nephrol 2011, 6:198-203.

56. Li JG, Ding J, Wang F, Zhang HW, et al: Drugs controlling proteinuria of patients with Alport syndrome. World J Pediatr 2009, 5:308-311.

57. Kashtan CE: Alport syndrome and thin glomerular basement membrane disease. J Am Soc Nephrol 1998, 9:1736-1750.

58. Sato Y, Wharram BL, Lee SK, Wickman L, Goyal M, Venkatareddy M, Chang JW, Wiggins JE, Lienczewski C, Kretzler M, Wiggins RC: Urine podocyte mRNAs mark progression of renal disease. J Am Soc Nephrol 2009, 20:1041-1052

59. Kriz W, LeHir M: Pathways to nephron loss starting from glomerular diseases-insights from animal models. Kidney Int 2005, 67:404-419.

60. Boor P, Ostendorf T, Floege J: Renal fibrosis: novel insights into mechanisms and therapeutic targets. Nat Rev Nephrol 2010, 6:643-656.

61. Zeisberg M, Neilson EG: Mechanisms of tubulointerstitial fibrosis. J Am SoC Nephrol 2010, 21:1819-1834.

62. Nangaku M: Mechanisms of tubulointerstitial injury in the kidney: final common pathways to end-stage renal failure. Intern Med 2004, 43:9-17.

63. Pippin JW, Brinkkoetter PT, Cormack-Aboud FC, Durvasula RV, Hauser PV, Kowalewska J, Krofft RD, Logar CM, Marshall CB, Ohse T, Shankland SJ: Inducible rodent models of acquired podocyte diseases. Am J Physiol Renal Physiol 2009, 296:F213-F229.

64. Kliem V, Johnson RJ, Alpers CE, Yoshimura A, Couser WG, Koch KM, Floege J: Mechanisms involved in the pathogenesis of tubulointerstitial fibrosis in 5/6-nephrectomized rats. Kidney Int 1996, 49:666-678.

65. Shimamura T, Morrison AB: A progressive glomerulosclerosis occurring in partial five-sixths nephrectomized rats. Am J Pathol 1975, 79:95-106.

66. Diamond JR, Karnovsky MJ: Focal and segmental glomerulosclerosis following a single intravenous dose of puromycin aminonucleoside. Am J Pathol 1986, 122:481-487.

67. Kim YH, Goyal M, Kurnit D, Wharram B, Wiggins J, Holzman L, Kershaw D, Wiggins R: Podocyte depletion and glomerulosclerosis have a direct relationship in the PAN-treated rat. Kidney Int 2001, 60:957-968.

68. Bugeon L, Danou A, Carpentier D, Langridge P, Syed N, Dallman MJ: Inducible gene silencing in podocytes: a new tool for studying glomerular function. J Am Soc Nephrol 2003, 14:786-791.

69. Shigehara T, Zaragoza C, Kitiyakara C, Takahashi H, Lu H, Moeller M, Holzman LB, Kopp JB: Inducible podocyte-specific gene expression in transgenic mice. J Am Soc Nephrol 2003, 14:1998-2003.

70. Assmann KJ, van Son JP, Dïkkman HB, Mentzel S, Wetzels JF: Antibodyinduced albuminuria and accelerated focal glomerulosclerosis in the Thy-1.1 transgenic mouse. Kidney Int 2002, 62:116-126.

71. Smeets B, Dijkman HB, te Loeke NA, van Son JP, Steenbergen EJ, Assmann KJ, Wetzels JF, Groenen PJ: Podocyte changes upon induction of 
albuminuria in Thy-1.1 transgenic mice. Nephrol Dial Transplant 2003, 18:2524-2533.

72. Chen A, Sheu LF, Ho YS, Lin YF, Chou WY, Chou TC, Lee WH: Experimental focal segmental glomerulosclerosis in mice. Nephron 1998, 78:440-452.

73. Lee W, Harris DC: Adriamycin nephropathy: a model of focal segmental glomerulosclerosis. Nephrology (Carlton) 2011, 16:30-38.

74. Van Beneden K, van Grunsven LA, Geers C, Pauwels M, Desmoulière A, Verbeelen D, Geerts A, Van den Branden C: CRBP-I in the renal tubulointerstitial compartment of healthy rats and rats with renal fibrosis. Nephrol Dial Transplant 2008, 23:3464-3471.

75. Wang Y, Wang YP, Tay YC, Harris DC: Progressive adriamycin nephropathy in mice: sequence of histologic and immunohistochemical events. Kidney Int 2000, 58:1797-1804.

76. Chevalier RL, Forbes MS, Thornhill BA: Ureteral obstruction as a model of renal interstitial fibrosis and obstructive nephropathy. Kidney Int 2009 75:1145-1152.

77. Bannister AJ, Kouzarides T: Regulation of chromatin by histone modifications. Cell Res 2011, 21:381-395.

78. Kouzarides T: Acetylation: a regulatory modification to rival phosphorylation? EMBO J 2000, 19:1176-1179.

79. Kouzarides T: Chromatin modifications and their function. Cell 2007, 128:693-705.

80. López-Rodas G, Brosch G, Georgieva El, Sendra R, Franco L, Loidl P: Histone deacetylase: A key enzyme for the binding of regulatory proteins to chromatin. FEBS Lett 1993, 317:175-180.

81. Spange $\mathrm{S}$, Wagner $\mathrm{T}$, Heinzel $\mathrm{T}$, Krämer $\mathrm{OH}$ : Acetylation of non-histone proteins modulates cellular signalling at multiple levels. Int J Biochem Cell Biol 2009, 41:185-198.

82. Norris KL, Lee JY, Yao TP: Acetylation goes global: the emergence of acetylation biology. Sci Signal 2009, 2:pe76.

83. Choudhary C, Kumar C, Gnad F, Nielsen ML, Rehman M, Walther TC, Olsen $\mathrm{J}$, Mann M: Lysine acetylation targets protein complexes and coregulates major cellular functions. Science 2009, 325:834-840.

84. Kim HJ, Bae SC: Histone deacetylase inhibitors: molecular mechanisms of action and clinical trials as anti-cancer drugs. Am J Trans/ Res 2011, 3:166-179.

85. de Ruijter AJ, van Gennip AH, Caron HN, Kemp S, van Kuilenburg AB: Histone deacetylases (HDACs): characterization of the classical HDAC family. Biochem J 2003, 370:737-749.

86. Johnstone RW: Histone-deacetylase inhibitors: novel drugs for the treatment of cancer. Nat Rev Drug Discov 2002, 1:287-299.

87. Khan N, Jeffers M, Kumar S, Hackett C, Boldog F, Khramtsov N, Qian X, Mills E, Berghs SC, Carey N, Finn PW, Collins LS, Tumber A, Ritchie JW, Jensen PB, Lichenstein HS, Sehested M: Determination of the class and isoform selectivity of small-molecule histone deacetylase inhibitors. Biochem $J$ 2008, 409:581-589.

88. Hallows WC, Lee S, Denu JM: Sirtuins deacetylate and activate mammalian acetyl-CoA synthetases. Proc Natl Acad Sci U S A 2006, 103:10230-10235.

89. Denu JM: The Sir 2 family of protein deacetylases. Curr Opin Chem Biol 2005, 9:431-440

90. Gray SG, Ekstrom TJ: The human histone deacetylase family. Exp Cell Res 2001, 262:75-83.

91. Marks PA, Xu WS: Histone deacetylase inhibitors: Potential in cancer therapy. J Cell Biochem 2009, 107:600-608.

92. Khabele D, Son DS, Parl AK, Goldberg GL, Augenlicht LH, Mariadason JM, Rice VM: Drug-induced inactivation or gene silencing of class I histone deacetylases suppresses ovarian cancer cell growth: implications for therapy. Cancer Biol Ther 2007, 6:795-801.

93. Saji S, Kawakami M, Hayashi S, Yoshida N, Hirose M, Horiguchi S, Itoh A, Funata N, Schreiber SL, Yoshida M, Toi M: Significance of HDAC6 regulation via estrogen signaling for cell motility and prognosis in estrogen receptor-positive breast cancer. Oncogene 2005, 24:4531-4539.

94. Taddei A, Roche D, Bickmore WA, Almouzni G: The effects of histone deacetylase inhibitors on heterochromatin: implications for anticancer therapy? EMBO Rep 2005, 6:520-524.

95. Takai N, Desmond JC, Kumagai T, Gui D, Said JW, Whittaker S, Miyakawa I, Koeffler HP: Histone deacetylase inhibitors have a profound antigrowth activity in endometrial cancer cells. Clin Cancer Res 2004, 10:1141-1149.
96. Williams SA, Chen LF, Kwon H, Ruiz-Jarabo CM, Verdin E, Greene WC: NF-kappaB p50 promotes HIV latency through HDAC recruitment and repression of transcriptional initiation. EMBO J 2006, 25:139-149.

97. Yoshida M, Kijima M, Akita M, Beppu T: Potent and specific inhibition of mammalian histone deacetylase both in vivo and in vitro by trichostatin A. J Biol Chem 1990, 265:17174-17179.

98. Sanderson L, Taylor GW, Aboagye EO, Alao JP, Latigo JR, Coombes RC, Vigushin DM: Plasma pharmacokinetics and metabolism of the histone deacetylase inhibitor trichostatin a after intraperitoneal administration to mice. Drug Metab Dispos 2004, 32:1132-1138.

99. Elaut G, Laus G, Alexandre E, Richert L, Bachellier P, Tourwé D, Rogiers V, Vanhaecke T: A metabolic screening study of trichostatin A (TSA) and TSA-like histone deacetylase inhibitors in rat and human primary hepatocyte cultures. J Pharmacol Exp Ther 2007, 321:400-408.

100. Fraczek J, Deleu S, Lukaszuk A, Doktorova T, Tourwé D, Geerts A, Vanhaecke $T$, Vanderkerken $K$, Rogiers $V$ : Screening of amide analogues of Trichostatin A in cultures of primary rat hepatocytes: search for potent and safe HDAC inhibitors. Invest New Drugs 2009, 27:338-346.

101. Richon VM, Emiliani S, Verdin E, Webb Y, Breslow R, Rifkind RA, Marks PA: A class of hybrid polar inducers of transformed cell differentiation inhibits histone deacetylases. Proc Natl Acad Sci U S A 1998, 95:3003-3007.

102. Vanhaecke T, Papeleu P, Elaut G, Rogiers V: Trichostatin A-like hydroxamate histone deacetylase inhibitors as therapeutic agents: toxicological point of view. Curr Med Chem 2004, 11:1629-1643.

103. Bieliauskas AV, Pflum MK: Isoform-selective histone deacetylase inhibitors. Chem Soc Rev 2008, 37:1402-1413.

104. Davis R, Peters DH, McTavish D: Valproic acid. A reappraisal of its pharmacological properties and clinical efficacy in epilepsy. Drugs 1994, 47:332-372.

105. Mannaerts I, Nuytten NR, Rogiers V, Vanderkerken K, van Grunsven LA, Geerts A: Chronic administration of valproic acid inhibits activation of mouse hepatic stellate cells in vitro and in vivo. Hepatology 2010, 51:603-614.

106. Van Beneden K, Geers C, Pauwels M, Mannaerts I, Verbeelen D, van Grunsven LA, Van den Branden C: Valproic acid attenuates proteinuria and kidney injury. J Am Soc Nephrol 2011, 22:1863-1875.

107. Blaheta RA, Michaelis M, Driever PH, Cinatl J Jr: Evolving anticancer drug valproic acid: insights into the mechanism and clinical studies. Med Res Rev 2005, 25:383-397.

108. Chateauvieux S, Morceau F, Dicato M, Diederich M: Molecular and therapeutic potential and toxicity of valproic acid. J Biomed Biotechnol 2010. doi:10.1155/2010/479364.

109. Göttlicher M, Minucci S, Zhu P, Krämer OH, Schimpf A, Giavara S, Sleeman JP, Lo Coco F, Nervi C, Pelicci PG, Heinzel T: Valproic acid defines a novel class of HDAC inhibitors inducing differentiation of transformed cells. EMBO J 2001, 20:6969-6978.

110. Gurvich N, Tsygankova OM, Meinkoth $J$, Klein PS: Histone deacetylase is a target of valproic acid-mediated cellular differentiation. Cancer Res 2004, 64:1079-1086.

111. Johannessen CU: Mechanisms of action of valproate: a commentatory. Neurochem Int 2000, 37:103-110.

112. Krämer $\mathrm{OH}$, Zhu P, Ostendorff HP, Golebiewski M, Tiefenbach J, Peters MA, Brill B, Groner B, Bach I, Heinzel T, Göttlicher M: The histone deacetylase inhibitor valproic acid selectively induces proteasomal degradation of HDAC2. EMBO J 2003, 22:3411-3420.

113. Lagace DC, O'Brien WT, Gurvich N, Nachtigal MW, Klein PS: Valproic acid: how it works. Or not. Clin Neurosci Res 2004, 4:215-225.

114. ClinicalTrials.gov: A service of the U. S. National Institutes of Health. 2012 www.clinicaltrials.gov.

115. Federico M, Bagella L: Histone deacetylase inhibitors in the treatment of hematological malignancies and solid tumors. J Biomed Biotechnol 2011, 2011:475-641.

116. Tan J, Cang S, Ma Y, Petrillo RL, Liu D: Novel histone deacetylase inhibitors in clinical trials as anti-cancer agents. J Hematol Oncol 2010, 3:5.

117. Niki T, Rombouts K, De Bleser P, De Smet K, Rogiers V, Schuppan D, Yoshida M, Gabbiani G, Geerts A: A histone deacetylase inhibitor, trichostatin A, suppresses myofibroblastic differentiation of rat hepatic stellate cells in primary culture. Hepatology 1999, 29:858-867.

118. Rombouts K, Niki T, Wielant A, Hellemans K, Geerts A: Trichostatin A, lead compound for development of antifibrogenic drugs. Acta Gastroenterol Belg 2001, 64:239-246. 
119. Rombouts K, Knittel T, Machesky L, Braet F, Wielant A, Hellemans K, De Bleser P, Gelman I, Ramadori G, Geerts A: Actin filament formation, reorganization and migration are impaired in hepatic stellate cells under influence of trichostatin A, a histone deacetylase inhibitor. J Hepatol 2002, 37:788-796.

120. Zhang L, Wan J, Jiang R, Wang W, Deng H, Shen Y, Zheng W, Wang Y: Protective effects of trichostatin A on liver injury in septic mice. Hepatol Res 2009, 39:931-938.

121. Finkelstein RA, Li Y, Liu B, Shuja F, Fukudome E, Velmahos GC, de Moya M, Alam HB: Treatment with histone deacetylase inhibitor attenuates MAP kinase mediated liver injury in a lethal model of septic shock. J Surg Res 2010, 163:146-154

122. Elsharkawy AM, Oakley F, Lin F, Packham G, Mann DA, Mann J: The NF-kappaB p50:p50:HDAC-1 repressor complex orchestrates transcriptional inhibition of multiple pro-inflammatory genes. J Hepatol 2010, 53:519-527.

123. Oakley F, Mann J, Nailard S, Smart DE, Mungalsingh N, Constandinou C, Ali S, Wilson SJ, Millward-Sadler H, Iredale JP, Mann DA: Nuclear factorkappaB1 ( $p 50$ ) limits the inflammatory and fibrogenic responses to chronic injury. Am J Pathol 2005, 166:695-708.

124. Lee SH, Zhao YZ, Park EJ, Che XH, Seo GS, Sohn DH: 2',4',6'-Tris (methoxymethoxy) chalcone induces apoptosis by enhancing Fas-ligand in activated hepatic stellate cells. Eur J Pharmacol 2011, 658:9-15.

125. Qin L, Han YP: Epigenetic repression of matrix metalloproteinases in myofibroblastic hepatic stellate cells through histone deacetylases 4 . implication in tissue fibrosis. Am J Pathol 2010, 177:1915-1928.

126. Shepard BD, Joseph RA, Kannarkat GT, Rutledge TM, Tuma DJ, Tuma PL: Alcohol-induced alterations in hepatic microtubule dynamics can be explained by impaired histone deacetylase 6 function. Hepatology 2008, 48:1671-1679

127. Watanabe T, Tajima H, Hironori H, Nakagawara H, Ohnishi I, Takamura H, Ninomiya I, Kitagawa H, Fushida S, Tani T, Fujimura T, Ota T, Wakayama T, Iseki S, Harada S: Sodium valproate blocks the transforming growth factor (TGF)-beta1 autocrine loop and attenuates the TGF-beta1-induced collagen synthesis in a human hepatic stellate cell line. Int J Mol Med 2011, 28:919-925.

128. Bai X, Wu L, Liang T, Liu Z, Li J, Li D, Xie H, Yin S, Yu J, Lin Q, Zheng S: Overexpression of myocyte enhancer factor 2 and histone hyperacetylation in hepatocellular carcinoma. J Cancer Res Clin Oncol 2008, 134:83-91.

129. Santamato A, Fransvea E, Dituri F, Caligiuri A, Quaranta M, Niimi T, Pinzani M, Antonaci S, Giannelli G: Hepatic stellate cells stimulate HCC cell migration via laminin-5 production. Clin Sci (Lond) 2011, 121:159-168.

130. Yang JD, Nakamura I, Roberts LR: The tumor microenvironment in hepatocellular carcinoma: current status and therapeutic targets. Semin Cancer Biol 2011, 21:35-43.

131. Amann T, Bataille F, Spruss T, Mühlbauer M, Gäbele E, Schölmerich J, Kiefer P, Bosserhoff AK, Hellerbrand C: Activated hepatic stellate cells promote tumorigenicity of hepatocellular carcinoma. Cancer Sci 2009 100:646-653.

132. van Zijl F, Mair M, Csiszar A, Schneller D, Zulehner G, Huber H, Eferl R, Beug $H$, Dolznig $H$, Mikulits W: Hepatic tumor-stroma crosstalk guides epithelial to mesenchymal transition at the tumor edge. Oncogene 2009, 28:4022-4033.

133. Sancho-Bru P, Juez E, Moreno M, Khurdayan V, Morales-Ruiz M, Colmenero J, Arroyo V, Brenner DA, Ginès P, Bataller R: Hepatocarcinoma cells stimulate the growth, migration and expression of pro-angiogenic genes in human hepatic stellate cells. Liver Int 2010, 30:31-41.

134. Rangwala F, Williams KP, Smith GR, Thomas Z, Allensworth JL, Lyerly HK, Diehl AM, Morse MA, Devi GR: Differential effects of arsenic trioxide on chemosensitization in human hepatic tumor and stellate cell lines. BMC Cancer 2012, 12:402.

135. Coulouarn C, Corlu A, Glaise D, Guénon I, Thorgeirsson SS, Clément B: Hepatocyte-stellate cell cross-talk in the liver engenders a permissive inflammatory microenvironment that drives progression in hepatocellular carcinoma. Cancer Res 2012, 72:2533-2542.

136. Zhang W, Kone BC: NF-kappaB inhibits transcription of the $\mathrm{H}(+)-\mathrm{K}$ (+)-ATPase alpha(2)-subunit gene: role of histone deacetylases. Am J Physiol Renal Physiol 2002, 283:F904-F911.

137. Yu Z, Zhang W, Kone BC: Histone deacetylases augment cytokine induction of the iNOS gene. J Am Soc Nephrol 2002, 13:2009-2017.

138. Yu Z, Kone BC: Targeted histone $\mathrm{H} 4$ acetylation via phosphoinositide 3-kinase- and p70s6-kinase-dependent pathways inhibits iNOS induction in mesangial cells. Am J Physiol Renal Physiol 2006, 290:F496-F502.
139. Freidkin I, Herman M, Tobar A, Chagnac A, Ori Y, Korzets A, Gafter U: Effects of histone deacetylase inhibitors on rat mesangial cells. Am J Physiol Renal Physiol 2010, 298:F426-F434.

140. Wang Q, Usinger W, Nichols B, Gray J, Xu L, Seeley TW, Brenner M, Guo G, Zhang W, Oliver N, Lin A, Yeowell D: Cooperative interaction of CTGF and TGF-beta in animal models of fibrotic disease. Fibrogenesis Tissue Repair 2011, 4:4.

141. Komorowsky C, Ocker M, Goppelt-Struebe M: Differential regulation of connective tissue growth factor in renal cells by histone deacetylase inhibitors. J Cell Mol Med 2009, 13:2353-2364.

142. Kroening S, Neubauer E, Wullich B, Aten J, Goppelt-Struebe M: Characterization of connective tissue growth factor expression in primary cultures of human tubular epithelial cells: modulation by hypoxia. Am J Physiol Renal Physiol 2010, 298:F796-F806.

143. Yoshikawa M, Hishikawa K, Marumo T, Fujita T: Inhibition of histone deacetylase activity suppresses epithelial-to-mesenchymal transition induced by TGF-beta1 in human renal epithelial cells. J Am Soc Nephrol 2007, 18:58-65.

144. Peinado H, Ballestar E, Esteller M, Cano A: Snail mediates E-cadherin repression by the recruitment of the $\operatorname{Sin} 3 \mathrm{~A} /$ histone deacetylase 1 (HDAC1)/HDAC2 complex. Mol Cell Biol 2004, 24:306-319.

145. Pang M, Zhuang S: Histone deacetylase: a potential therapeutic target for fibrotic disorders. J Pharmacol Exp Ther 2010, 335:266-272.

146. Arany I, Herbert J, Herbert Z, Safirstein RL: Restoration of CREB function ameliorates cisplatin cytotoxicity in renal tubular cells. Am J Physiol Renal Physiol 2008, 294:F577-F581.

147. Dong G, Luo J, Kumar V, Dong Z: Inhibitors of histone deacetylases suppress cisplatin-induced p53 activation and apoptosis in renal tubular cells. Am J Physiol Renal Physiol 2010, 298:F293-F300.

148. Dong G, Wang L, Wang CY, Yang T, Kumar MV, Dong Z: Induction of apoptosis in renal tubular cells by histone deacetylase inhibitors, a family of anticancer agents. J Pharmacol Exp Ther 2008, 325:978-984.

149. Yoshikawa M, Hishikawa K, Idei M, Fujita T: Trichostatin a prevents TGFbeta1-induced apoptosis by inhibiting ERK activation in human renal tubular epithelial cells. Eur J Pharmacol 2010, 642:28-36.

150. Pang M, Ma L, Liu N, Ponnusamy M, Zhao TC, Yan H, Zhuang S: Histone deacetylase $1 / 2$ mediates proliferation of renal interstitial fibroblasts and expression of cell cycle proteins. J Cell Biochem 2011, 112:2138-2148.

151. Marumo T, Hishikawa K, Yoshikawa M, Hirahashi J, Kawachi S, Fujita T: Histone deacetylase modulates the proinflammatory and -fibrotic changes in tubulointerstitial injury. Am J Physiol Renal Physiol 2010 298:F133-F141.

152. Li HF, Cheng CF, Liao WJ, Lin H, Yang RB: ATF3-mediated epigenetic regulation protects against acute kidney injury. J Am Soc Nephrol 2010, 21:1003-1013.

153. Kinugasa F, Noto T, Matsuoka H, Urano Y, Sudo Y, Takakura S, Mutoh S. Prevention of renal interstitial fibrosis via histone deacetylase inhibition in rats with unilateral ureteral obstruction. Transp/ Immuno/ 2010, 23:18-23.

154. Pang M, Kothapally J, Mao H, Tolbert E, Ponnusamy M, Chin YE, Zhuang S: Inhibition of histone deacetylase activity attenuates renal fibroblast activation and interstitial fibrosis in obstructive nephropathy. Am J Physiol Renal Physiol 2009, 297:F996-F1005.

155. Advani A, Huang Q, Thai K, Advani SL, White KE, Kelly DJ, Yuen DA, Connelly KA, Marsden PA, Gilbert RE: Long-term administration of the histone deacetylase inhibitor vorinostat attenuates renal injury in experimental diabetes through an endothelial nitric oxide synthase-dependent mechanism. Am J Pathol 2011, 178:2205-2214.

156. Gilbert RE, Huang Q, Thai K, Advani SL, Lee K, Yuen DA, Connelly KA, Advani A: Histone deacetylase inhibition attenuates diabetes-associated kidney growth: potential role for epigenetic modification of the epidermal growth factor receptor. Kidney Int 2011, 79:1312-1321.

157. Noh H, Oh EY, Seo JY, Yu MR, Kim YO, Ha H, Lee HB: Histone deacetylase-2 is a key regulator of diabetes- and transforming growth factor-beta1induced renal injury. Am J Physiol Renal Physiol 2009, 297: F729-F739.

158. Marumo T, Hishikawa K, Yoshikawa M, Fujita T: Epigenetic regulation of BMP7 in the regenerative response to ischemia. J Am Soc Nephrol 2008 , 19:1311-1320.

159. Zacharias N, Sailhamer EA, Li Y, Liu B, Butt MU, Shuja F, Velmahos GC, de Moya M, Alam HB: Histone deacetylase inhibitors prevent apoptosis following lethal hemorrhagic shock in rodent kidney cells. Resuscitation 2011, 82:105-109. 
160. Brilli LL, Swanhart LM, de Caestecker MP, Hukriede NA, et al: HDAC inhibitors in kidney development and disease. Pediatr Nephrol 2012. doi:10.1007/s00467-012-2320-8.

161. Shakespear MR, Halili MA, Irvine KM, Fairlie DP, Sweet MJ: Histone deacetylases as regulators of inflammation and immunity. Trends Immunol 2011, 32:335-343.

162. Sweet MJ, Shakespear MR, Kamal NA, Fairlie DP: HDAC inhibitors: modulating leukocyte differentiation, survival, proliferation and inflammation. Immunol Cell Biol 2012, 90:14-22.

163. Wang D: Computational studies on the histone deacetylases and the design of selective histone deacetylase inhibitors. Curr Top Med Chem 2009, 9:241-256.

164. Hellebrekers DM, Griffioen AW, van Engeland M: Dual targeting of epigenetic therapy in cancer. Biochim Biophys Acta 2006, 1775:7-91.

165. Yi TZ, Li J, Han X, Guo J, Qu Q, Guo L, Sun HD, Tan WH: DNMT inhibitors and HDAC Inhibitors regulate E-Cadherin and Bcl-2 expression in endometrial carcinoma in vitro and in vivo. Chemotherapy 2012, 58:19-29.

166. Mann DA, Mann J: Epigenetic regulation of hepatic stellate cell activation. J Gastroenterol Hepatol 2008, 23(Suppl 1):S108-S111.

167. Mann J, Chu DC, Maxwell A, Oakley F, Zhu NL, Tsukamoto H, Mann DA: MeCP2 controls an epigenetic pathway that promotes myofibroblast transdifferentiation and fibrosis. Gastroenterology 2009, 138:705-714.

168. Mann J, Oakley F, Akiboye F, Elsharkawy A, Thorne AW, Mann DA: Regulation of myofibroblast transdifferentiation by DNA methylation and MeCP2: implications for wound healing and fibrogenesis. Cell Death Differ 2007, 14:275-285.

169. Kee HJ, Kook H: Roles and targets of class I and lla histone deacetylases in cardiac hypertrophy. J Biomed Biotechnol 2011, 2011:928326.

170. Wiech NL, Fisher JF, Helquist P, Wiest O: Inhibition of histone deacetylases: a pharmacological approach to the treatment of non-cancer disorders. Curr Top Med Chem 2009, 9(3):257-271.

171. Rishikof DC, Ricupero DA, Liu H, Goldstein RH: Phenylbutyrate decreases type I collagen production in human lung fibroblasts. I Cell Biochem 2004, 91:740-748.

Cite this article as: Van Beneden et al:: HDAC inhibitors in experimental liver and kidney fibrosis. Fibrogenesis \& Tissue Repair 2013 6:1.

\section{Submit your next manuscript to BioMed Central and take full advantage of:}

- Convenient online submission

- Thorough peer review

- No space constraints or color figure charges

- Immediate publication on acceptance

- Inclusion in PubMed, CAS, Scopus and Google Scholar

- Research which is freely available for redistribution 